\title{
THE FISCAL FRAME OF NATIONAL TRANSPORT SERVICES ASSIMILATED TO INTRA-COMMUNITARIAN GOODS TRANSPORT, ACCESSORY SERVICES AND AFFERENT MEDIATION SERVICES
}

\author{
Pravăt Ionela-Cristina, Assistant \\ UNIVERSITY OF BACĂU
}

\begin{abstract}
: the point $f$ view of some short examples.

\section{The national transport assimilated to intra-communitarian transport}

The national transport, from a
\end{abstract}

The unrolling of properly intra-communitarian goods transport services may depend in many cases or be in tight connection with other services performance, such as: national transport services, accessory services (loading, unloading, handling, weighing, sorting, goods storage) or the mediation services concerning the intra-communitarian goods transport or accessory services.

The categories of services above mentioned are remarked through a series of specific fiscal aspects, aspects that will be presented in this paper, both from a theoretical point of view, and from departure point up to a arrival point, both from Romania's territory, is assimilated to an intra-communitarian goods transport, with the condition that the national transport will be in direct connection with intra-communitarian transport. Meaning, even a transport made inside the same country may be framed in the category of "intra-communitarian transport", in the case when it is connected from a properly intra-communitarian transport. For instance, the transport realized from the border of a Member State up to the arrival point established inside the country is classified as intra-communitarian transport, if it is performed according to a transport from a country belonging to European Union.

In order for the national transport to enter under the incidence of intracommunitarian goods transport regulation, this should respect the following conditions:

- the contract or any other document afferent to transport should exist in the moment of concluding the intracommunitarian goods transport;

- the person that performs the national transport assimilated to intra-communitarian goods transport should action in the place of the person who orders or realizes the intracommunitarian goods transport;

- the goods will depart from Romania in the same state in which they were at the beginning of the transport assimilated to intracommunitarian goods transport.

Example no. 1: S.C. INTRACOM TRANSPORT S.R.L., established and registered in VAT purposes in Romania, transports goods from Suceava to Bucharest (between two towns in Romania), for S.C. MEDRO S.R.L., established and registered in VAT purposes for Romania as well. The goods will be transported from Bucharest to Sofia, in Bulgaria.

If the conditions above mentioned are respected and the national transport part is in direct connection with the intracommunitarian transport, then the national goods transport, from Suceava to Bucharest, will be assimilated to intra-communitarian goods transport and will enter under the incidence of the rules afferent to it.

Example no. 2: MONDOFRANCE society, established and registered in VAT purposes for France, transports goods from France (Paris) to Romania (Buzau), for ASCOROM S.R.L. society from Romania. The goods are initially transported by train to Romania, in Bucharest, and then are domestically transported, by road, to Buzau (final destination).

If the conditions above mentioned are respected and the national transport part is in direct connection with the intracommunitarian transport, then the national goods transport, from Bucharest to Buzau, 
will be assimilated to intra-communitarian transport and will also enter under the incidence of the rules afferent to it.

Taking under consideration the fact that under these types of cases, as already mentioned, the national transport is assimilated to intra-communitarian transport and submitted to the fiscal rules specific for the latter, the place of the national transport performance would be:

- the departure place of the transport, if the beneficiary does not communicate a registration code in VAT purposes, the taxing being realized in that Member State from where the goods departured, the invoice containing VAT;

the Member State where the beneficiary is established, respective another Member State, if the beneficiary communicates a registration code in VAT purposes available in the Member State where is established, or in any Member State (with the exception of the state where the performer is situated), the taxing being realized in that Member State where the VAT code is available and not in the transporter's state, the invoice being issued without VAT.

\section{Services accessory to intra- communitarian goods transport}

Services accessory to goods transport, in general, intra-communitarian goods transport, in particular, consist of: loading, unloading, handling, weighing, sorting, goods storage.

The place of performance of the accessory services for an intracommunitarian goods transport is normally the place where the services are actually performed. By exception, if the services are performed for a beneficiary that communicates a registration code in VAT purposes available in another Member State than the one where the services are effectively performed, the performance place is represented by the Member State that issued the VAT code, in whose basis the services were performed to the beneficiary.

The person obliged to VAT purpose in Romania is, normally, the services' performer. By exception, the person obliged to VAT purpose is the beneficiary, in the following cases:

- the services performer is not established in Romania, even if is registered in VAT purposes in Romania; and

- the beneficiary is registered in VAT purposes in Romania.

Example: $\quad$ S.C. INTRACOM TRANSPORT S.R.L., established and registered in VAT purposes in Romania, transports goods from Spain (Castellon) to Romania (Bucharest) for S.C. MEDRO S.R.L. society, established and registered in VAT purposes in Romania as well. The transport operation will be realized on water from Castellon to Rome, and from here the transport is realized on road. In this situation the accessory services intervene, respective the loading/unloading performed by a society established and registered in VAT purposes in Italy. To the latter the registration code in VAT purposes in Romania is communicated by S.C. MEDRO S.R.L..

The applicable fiscal treatment is the following:

In this case, because the beneficiary society communicated its VAT registration code available in Romania, the place of performance will be considered Romania and not Italy, and the beneficiary will tax the operation in Romania, by inverse taxation.

The beneficiary, S.C. MEDRO S.R.L., will receive an invoice without VAT, but will highlight in accountancy both deductible and collected VAT in VAT deduction.

3. The mediation services concerning the intra-communitarian goods transport and the accessory services

The mediation services represent that category of services that are performed by a person (mandatory) that takes action in the name of another person (mandate). The mediation service is practically a performance of services made by mandatory for the mandate.

In consequence, in the case of intracommunitarian goods transport may appear situations where, by different reasons, the supplier or beneficiary is under the impossibility of making on their own the 
transport and sues to intermediaries that can find, for them, a society that will realize effectively the goods transport.

The performance place for the mediation services connected to an intracommunitarian goods transport is considered to be the Member State where the goods transport begins or, by exception, the Member State that attributed the VAT code in whose basis the service was performed, if the service is performed for a beneficiary that communicates a valid VAT code (with prefix) from another Member State than the one from where the intra-communitarian goods transport began.

The performance place for the mediation services of the accessory services for an intra-communitarian goods transport is considered to be the place where the accessory services are effectively performed or, by exception, the Member State that attributed the VAT code in whose basis the service was performed to beneficiary, if the service performed to a beneficiary that communicates a valid VAT code (with prefix) from another Member State than the one where the accessory services were effectively performed.

The person obliged to VAT payment in Romania for mediation services connected to accessory services of an intracommunitarian goods transport or for the mediation services connected by accessory services to an intra-communitarian transport that takes place in Romania is normally the performer.

By exception, the person obliged to VAT payment is the beneficiary, if the following conditions are simultaneously satisfied:

- the performer is not established in Romania, even though he is registered in VAT purposes in Romania;

- the beneficiary is registered in VAT purposes in Romania.

Example: S.C. X S.A. society established and registered in VAT purposes in Romania, purchases goods from a society from Bulgaria, goods that follows to be transported on water from Bulgaria to Romania.

S.C. X S.A. mandatates the S.C. Y S.R.L., society also established in Romania, to find a society that would perform the goods handling and loading on the ship in Bulgaria. S.C. Y S.R.L. makes contact to the $\mathrm{Z}$ society from Bulgaria for this service. following:

The applicable fiscal treatment is the

Under this condition, S.C. Y S.R.L. performs a mediation service afferent to accessory services for intra-communitarian goods transport, that takes place in Romania. $\mathrm{Y}$ is the person obliged to VAT payment in Romania because is established and registered in VAT purposes in Romania. S.C. Y S.R.L will issue towards S.C. X S.A an invoice with VAT $19 \%$, quota available for Romania

\section{References:}

[1] Dumitrana, M., Jalbă, L., Duţă, O., Accountancy in trade and tourism, University Publish house, Bucharest, 2008;

[2] Popa, A.F., Popa, N., The excises and taxes settled by The Fiscal Code, CONTAPLUS Publish house, Bucharest, 2008;

[3] Popa, A.F., Radu, G., Popa, N., Iordan-Brăduț, C., The Fiscal Code in the context of European adhesion: practical guide for comprehension and appliance, CONTAPLUS Publish house, Bucharest;

[4] *** The Order of the Public Finances Ministry no. 1752/2005 for approving the Accountancy settlements according to European directives, published in Official Monitor, Part I no. 1080 from 30/11/2005 with subsequent changes and completions;

[5] *** Law no. 571/2003 concerning The Fiscal Code, published in Official Monitor no. $927 / 23.12 .2003$;

[6] *** Law no. 343/2006, for changing and completion the Law no. 571/2003 concerning The Fiscal Code, published in Official Monitor no. 662/01.08.2006; 
80 The fiscal frame of national transport services assimilated to intra-Communitarian goods transport, accesory services and afferent mediations services

[7] *** The Order of The National Agency of Fiscal Administration's President no. 3/2007 concerning the request procedure of the fiscal registration in VAT purpose for traders that register in VAT purposes from the establishing, published in Official Monitor no. 19/11.01.2007;

[8] http://infotva.mfinante.ro;

[9] http://codfiscal.net. 